\title{
Prospects for development of Ukraine and EU in the field of renewable energy sources
}

\author{
Mykola Khomenko ${ }^{1, *}$, Kateryna Pryakhina ${ }^{2}$, and Kostyantyn Latyshev ${ }^{3}$ \\ ${ }^{1}$ Doctor of Economics, professor, Kremenchuk Mykhailo Ostrohradskyi National University, Ukraine \\ ${ }^{2} \mathrm{PhD}$ candidate, Kremenchuk Mykhailo Ostrohradskyi National University, Ukraine \\ ${ }^{3} \mathrm{PhD}$, associate professor, Kremenchuk Mykhailo Ostrohradskyi National University, Ukraine
}

\begin{abstract}
In article assessment of tendencies and prospects of cooperation between Ukraine and the European Union in the field of renewable energy sources was carried out. Over the past decades, the theme of climate change, especially caused by human activity, has become one of the most acute and most exploited in scientific disputes. Today, the problem of finding new sources of energy is more than acute, with a special place occupy non-traditional ones. The reduction of Ukraine's energy dependence on traditional fuel resources is possible only through the development and use own alternative energy, which uses local resources - bioenergy as a fuel or does not require a fuel component at all - solar, wind and small hydropower. The European Union is one of the leaders in the implementation of alternative energy and renewable energy sources and initiates the creation of many organizations that finance alternative energy projects. Ukraine should ensure the effective convergence of its own legislation with the European Union, since it defined the European integration vector as a priority area of foreign policy development. At the same time, within the framework of the Union, the mechanism of environmental protection and progressive approaches to the implementation of energy policy, including in the field of renewable energy, can serve as the most constructive benchmarks for Ukraine's development in this area. Ukraine signed the Paris Agreement, and undertook certain commitments, namely: in accordance with the National Action Plan on alternative energy up to 2020, the objective was to reach $11 \%$ of RES in gross final energy consumption. Achieving this goal is possible only in the case of international cooperation with the EU in the field of alternative energy. However, today, the study of the prospects of cooperation between Ukraine and the EU in this field is not developing sufficiently and there is a certain vacuum in solving strategic problems in this context, which determines the relevance of the topic.
\end{abstract}

Key words: renewable energy sources (RES), Energy Strategy, European Union (EU), Total Primary Energy Supply (TPES), Energy Strategy of Ukraine (ESU).

\footnotetext{
*Corresponding author: katerinapryakhina@gmail.com
} 


\section{Introduction}

The development of renewable energy sources is a very urgent issue for Ukraine, especially in the context of developing cooperation with the European Union. Alternative energy sources are renewable energy sources that include solar, wind, geothermal, wave and tidal energy, hydropower, biomass energy, organic waste gas, sewage treatment plant gas, biogas, and secondary energy resources, which include blast furnaces and coking gases, methane gas for the degassing of coal deposits, transformation of the waste energy potential of technological processes. Renewable energy sources are renewable non-expanding sources of energy, namely solar, wind, aerot energy thermal, geothermal, hydrothermal, energy of waves and tides, hydropower, biomass energy, gas from organic waste, gas of sewage treatment plants, biogas [1].

The main stages of the study are determined for assessment of tendencies and prospects of cooperation between Ukraine and the European Union in the field of renewable energy sources:

- the value of alternative energy in the economy of Ukraine and the European Union;

- research of historical preconditions of cooperation between Ukraine and the European Union in the field of alternative energy;

- analysis of the current state of alternative energy sources in Ukraine;

- definition of promising directions of development of cooperation between Ukraine and the EU in the field of RES.

\section{Data and Methods}

Dialectical and historical approaches used to study the historical preconditions for cooperation between Ukraine and the European Union in the field of alternative energy. The system approach was used to assess the current state of alternative energy sources in Ukraine and the countries of Europe and analysis of Ukraine's energy strategy. For this purpose, the statistical indicators are used. Major projects on cooperation between Ukraine and the EU in the field of RES are analyzed and synthesized on perspective directions of development of Ukraine-EU cooperation in the field of alternative energy. The object of the study is the processes of establishing cooperation between Ukraine and the EU in the of RES. The subject of the study is the assessment of RES in Ukraine and EU countries.

\section{Results}

\subsection{The value of Renewable energy sources in the farms of Ukraine and the European Union}

Information on the amount of energy from renewable sources from the EU countries is given in Table 1. 
Table 1. The share of RES in EU farms (\% of gross final energy consumption)

\begin{tabular}{|l|c|c|c|c|c|c|}
\hline & 2004 & 2012 & 2013 & 2014 & 2015 & $\begin{array}{c}2020 \\
\text { (goal) }\end{array}$ \\
\hline EU & 8,5 & 14,4 & 15,2 & 16,1 & 16,7 & 20 \\
\hline Belgium & 1,9 & 7,2 & 7,5 & 8,0 & 7,9 & 13 \\
\hline Bulgaria & 9,4 & 16,0 & 19,0 & 18,0 & 18,2 & 16 \\
\hline Czech Republic & 6,8 & 12,8 & 13,8 & 15,1 & 15,1 & 13 \\
\hline Denmark & 14,9 & 25,7 & 27,4 & 29,3 & 30,8 & 30 \\
\hline Germany & 5,8 & 12,1 & 12,4 & 13,8 & 14,6 & 18 \\
\hline Estonia & 18,4 & 25,8 & 25,6 & 26,3 & 28,6 & 25 \\
\hline Ireland & 2,4 & 7,2 & 7,7 & 8,7 & 9,2 & 16 \\
\hline Greece & 6,9 & 13,5 & 15,0 & 15,3 & 15,4 & 18 \\
\hline Spain & 8,3 & 14,3 & 15,3 & 16,1 & 16,2 & 20 \\
\hline France & 9,4 & 13,4 & 14,1 & 14,7 & 15,2 & 23 \\
\hline Croatia & 23,5 & 26,8 & 28,0 & 27,9 & 29,0 & 20 \\
\hline Italy & 6,3 & 15,4 & 16,7 & 17,1 & 17,5 & 17 \\
\hline Cyprus & 3,1 & 6,8 & 8,1 & 8,9 & 9,4 & 13 \\
\hline Latvia & 32,8 & 35,7 & 37,1 & 38,7 & 37,6 & 40 \\
\hline Lithuania & 17,2 & 21,4 & 22,7 & 23,6 & 25,8 & 23 \\
\hline Luxembourg & 0,9 & 3,1 & 3,5 & 4,5 & 5,0 & 11 \\
\hline Hungary & 4,4 & 15,5 & 16,2 & 14,6 & 14,5 & 13 \\
\hline Malta & 0,1 & 2,8 & 3,7 & 4,7 & 5,0 & 10 \\
\hline Netherlands & 2,1 & 4,7 & 4,8 & 5,5 & 5,8 & 14 \\
\hline Austria & 22,6 & 31,4 & 32,3 & 32,8 & 33,0 & 34 \\
\hline Poland & 6,9 & 10,9 & 11,4 & 11,5 & 11,8 & 15 \\
\hline Portugal & 19,2 & 24,6 & 25,7 & 27,0 & 28,0 & 31 \\
\hline Romania & 16,3 & 22,8 & 23,9 & 24,8 & 24,8 & 24 \\
\hline Slovenia & 16,1 & 20,8 & 22,4 & 21,5 & 22,0 & 25 \\
\hline Slovakia & 6,4 & 10,4 & 10,1 & 11,7 & 12,9 & 14 \\
\hline Finland & 29,2 & 34,4 & 36,7 & 38,7 & 39,3 & 38 \\
\hline Sweden & 38,7 & 51,1 & 52,0 & 52,5 & 53,9 & 49 \\
\hline UK & 1,1 & 4,6 & 5,7 & 7,1 & 8,2 & 15 \\
\hline Iceland & 58,9 & 72,5 & 71,7 & 70,5 & 70,2 & 64 \\
\hline Norway & 58,1 & 65,6 & 66,7 & 69,4 & 69,4 & 67,5 \\
\hline Albania & 28,1 & 35,2 & 33,2 & 32,0 & 34,9 & 38 \\
\hline Montenegro & - & 41,6 & 43,7 & 44,1 & 43,1 & 33 \\
\hline Republic of Macedonia & 15,7 & 18,1 & 18,5 & 19,6 & 19,9 & 28 \\
\hline Turkey & 16,2 & 13,1 & 14,0 & 13,7 & 13,6 & - \\
\hline
\end{tabular}

Source: [2].

Thus, at the end of 2015 , the share of alternative energy was $16.7 \%$, which is close to the planned $20 \%$ target, which the European Union is planning to achieve no later than 2020 .

So, Sweden is the leader in this indicator, which receives more than half $-53.9 \%$ of the required energy from renewable sources. Immediately, we note that Norway and Iceland have much higher rates $-69.4 \%$ and $70.2 \%$ respectively, but these countries are not part of the European Union. Eleven of the 28 EU Member States have already reached their target. It should be noted that in 2014, the share of renewable energy in the EU was $16.1 \%$, and in 2004, when Eurostat first published such statistics, this figure was only $8.5 \%$. By 2030, the EU plans to reach at least $27 \%$ of renewable energy [3]. 


\subsection{Stages of the development of cooperation in the field of RES in Ukraine and the EU}

In tabl. 1.2 provides the main stages of establishing cooperation between Ukraine and the European Union in the field of RES. In the process of establishing cooperation, you can distinguish five main and most significant stages.

Table 2. Stages of the development of cooperation in the field of RES in Ukraine and the EU

\begin{tabular}{|c|c|c|}
\hline Stage & $\begin{array}{l}\text { Date of the } \\
\text { beginning } \\
\text { of the stage }\end{array}$ & Content \\
\hline 1 & $\begin{array}{l}\text { May 9, } \\
1992\end{array}$ & $\begin{array}{l}\text { On May 9, 1992, at the international summit in Rio de Janeiro, most } \\
\text { countries in the world, including Ukraine, signed an agreement on } \\
\text { sustainable development, which ensures the reproduction of a living } \\
\text { standard without degradation of the environment. The agreement was } \\
\text { named the United Nations Framework Convention on Climate Change. } \\
\text { It came into force on March 21, } 1994 \text { [4]. }\end{array}$ \\
\hline 2 & $\begin{array}{l}\text { February 4, } \\
2004\end{array}$ & $\begin{array}{l}\text { In 2004, the Verkhovna Rada of Ukraine adopted the Law "On } \\
\text { Ratification of the Kyoto Protocol to the UN Framework Convention on } \\
\text { Climate Change". The signing and ratification of the Kyoto Protocol } \\
\text { allowed the determination of commitments, the establishment of } \\
\text { specific goals and mechanisms for their achievement. The Kyoto } \\
\text { Protocol came into force on February } 16,2005 \text { [4]. }\end{array}$ \\
\hline 3 & $\begin{array}{l}\text { December } \\
7-18,2009\end{array}$ & $\begin{array}{l}\text { In December 2009, the United Nations Climate Change Conference in } \\
\text { Copenhagen ended with "taking into account" the extremely } \\
\text { controversial compromise document "Copenhagen Accord", the future } \\
\text { of which is unclear. Most States acknowledge that the Kyoto Protocol to } \\
\text { the Framework Convention on Climate Change is ineffective and needs } \\
\text { to be replaced by a document that would involve both developed and } \\
\text { developing countries, which already account for most of the global } \\
\text { greenhouse gas emissions [1]. }\end{array}$ \\
\hline 4 & $\begin{array}{l}\text { December } \\
8,2012\end{array}$ & $\begin{array}{l}\text { Due to the expiration of the Kyoto Protocol, the Eighteenth United } \\
\text { Nations Climate Change Conference was held in Doha, Qatar in 2012, } \\
\text { which resulted in agreement to extend the Kyoto Protocol from } 2013 \text { to } \\
2020 \text { [3]. }\end{array}$ \\
\hline 5 & $\begin{array}{l}\text { July 14, } \\
2016\end{array}$ & $\begin{array}{l}\text { On April 22, } 2016 \text { Ukraine signed the Paris Agreement on combating } \\
\text { climate change, and on July 14, 2016, the agreement was ratified by the } \\
\text { Verkhovna Rada [5]. }\end{array}$ \\
\hline 6 & $\begin{array}{l}\text { December } \\
27,2017\end{array}$ & $\begin{array}{l}\text { On December 27, President of Ukraine Petro Poroshenko signed the } \\
\text { Law of Ukraine "On the Accession of Ukraine to the Statute of the } \\
\text { International Agency for Renewable Energy Sources (IRENA)". } \\
\text { Membership in IRENA will allow Ukraine to more actively develop the } \\
\text { renewable energy sector to reduce energy dependence. It has the } \\
\text { expertise of other IRENA member countries to do this. }\end{array}$ \\
\hline
\end{tabular}

Source: Own processing.

Thus, the international cooperation of Ukraine with the EU in the field of alternative energy has been going on for 25 years now. During this time, Ukraine has achieved some results in the field of alternative energy and use of RES. Therefore, it will be necessary to carry out an analysis of the state of affairs of Ukraine in the field of alternative energy, to allocate the most promising RES, which is provided by the state, as well as to analyze energy strategies of the leading European countries. 


\subsection{Analysis of the current state of alternative energy sources in Ukraine}

Energy Strategy of Ukraine for the period up to 2035 "Safety, Energy Efficiency, Competitiveness" dated September 25, 2017 provides that by 2025 Ukraine's energy sector reform will be completed and priority targets for security and energy efficiency achieved, innovation renewal and integration with the energy sector of the EU will be ensured [6].

Despite global trends in the use of alternative energy, Ukraine is still lagging far behind developed countries. According to Eurostat by September 2017, only 6\% of the energy produced in Ukraine was produced using renewable energy sources [7]. However, this is a significant progress, as in 2016, the RES contribution to the overall energy balance was only $1.05-1.16 \%$.

In 2015, the Total Primary Energy Supply structure of Ukraine was characterized by a high proportion of natural gas of $28.9 \%$, (26.1 million tons of oil equivalent). The share of nuclear power was $25.5 \%$ (23.0 million tons of oil equivalent); coal - 30.4\% (27.3 million tons of oil equivalent); crude oil and petroleum products $-11.6 \%$ (10.5 million tons of oil equivalent); biomass (biomass, fuel and waste) $-2.3 \%$ (2.1 million tons of oil equivalent); Hydroelectric power station - 0,5\% ( 0,5 million tons of oil equivalent); thermal energy (thermal energy of the environment and waste resources of technogenic origin $)-0.5 \%(0.5$ million tons of oil equivalent) and WEU and SES together $-0.1 \%(0.1$ million tons of oil equivalent). The total share of all RES was 3.6 million tons, or only $4 \%$ (Table 3 ) [8].

Table 3. Total Primary Energy Supply structure of Ukraine, million tons of oil equivalent

\begin{tabular}{|l|c|c|c|c|c|c|}
\hline $\begin{array}{l}\text { Name of the source } \\
\text { of TPES }\end{array}$ & 2010 & 2015 & $\begin{array}{c}2020 \\
\text { (forecast) }\end{array}$ & $\begin{array}{c}2025 \\
\text { (forecast) }\end{array}$ & $\begin{array}{c}2030 \\
\text { (forecast) }\end{array}$ & $\begin{array}{c}2035 \\
\text { (forecast) }\end{array}$ \\
\hline Coal & 38,3 & 27,3 & 18 & 14 & 13 & 12 \\
\hline Natural gas & 55,2 & 26,1 & 24,3 & 27 & 28 & 29 \\
\hline Petroleum products & 13,2 & 10,5 & 9,5 & 8 & 7,5 & 7 \\
\hline Atomicenergy & 23,4 & 23,0 & 24 & 28 & 27 & 24 \\
\hline $\begin{array}{l}\text { Biomass, biofuels } \\
\text { and waste }\end{array}$ & 1,5 & 2,1 & 4 & 6 & 8 & 11 \\
\hline $\begin{array}{l}\text { Solar and wind } \\
\text { power }\end{array}$ & 0,0 & 0,1 & 1 & 2 & 5 & 10 \\
\hline HPP & 1,1 & 0,5 & 1 & 1 & 1 & 1 \\
\hline Thermal energy & 0,5 & 0,5 & 1 & 1 & 1,5 & 2 \\
\hline Total & 132,3 & 90,1 & 82,3 & 87 & 91 & 96 \\
\hline
\end{tabular}

Source: [8], own processing.

The nuclear power plants will remain the base power of Ukraine, and by 2035 their share in the overall energy balance will be more than 50\%. An important task in this situation is diversification of nuclear fuel supplies. The role of coal generation in the energy balance by 2035 will remain significant $-25-30 \%$, which will require supplies in excess of 20 million tons of coal per year. Ensuring own production at competitive prices will be an important component of Ukraine's energy security [6]. Regarding alternative energy, the Strategy envisages a steady expansion of the use of all types of renewable energy, which will become one of the tools for guaranteeing the energy security of the state (Table 4). 
Table 4. The share of RES in the energy balance of Ukraine

\begin{tabular}{|l|c|c|c|c|c|}
\hline Description of the key performance indicator & 2015 & 2020 & 2025 & 2030 & 2035 \\
\hline $\begin{array}{l}\text { Share of RES (including hydro generating capacity } \\
\text { and thermal energy) in TPES, } \%\end{array}$ & $4 \%$ & 8 & 12 & 17 & 25 \\
\hline $\begin{array}{l}\text { The share of RES (including hydro generating } \\
\text { capacity) in electricity generation, } \%\end{array}$ & 5 & 7 & 10 & 13 & 25 \\
\hline $\begin{array}{l}\text { The share of local alternative sources of oil in local } \\
\text { fuel and energy balances, } \% \text { of total consumption }\end{array}$ & & 10 & 15 & 18 & 20 \\
\hline
\end{tabular}

Source: [6], own processing.

In the short to medium term (by 2025), the ESU predicts an increase in the share of renewable energy to $12 \%$ of the TPES and at least $25 \%$ by 2035 (including all hydro generating capacities and thermal energy).

The main RES in Ukraine is wind and solar energy, as well as biomass. In addition, large hydroelectric plants make their contribution, but small hydroelectric power stations are almost not built. In 2016, the objects of alternative energy budo produced 1.7 billion $\mathrm{kWh}$, and in 2017 to produce 1.9 billion $\mathrm{kWh}$, which is $11.76 \%$ more [8].

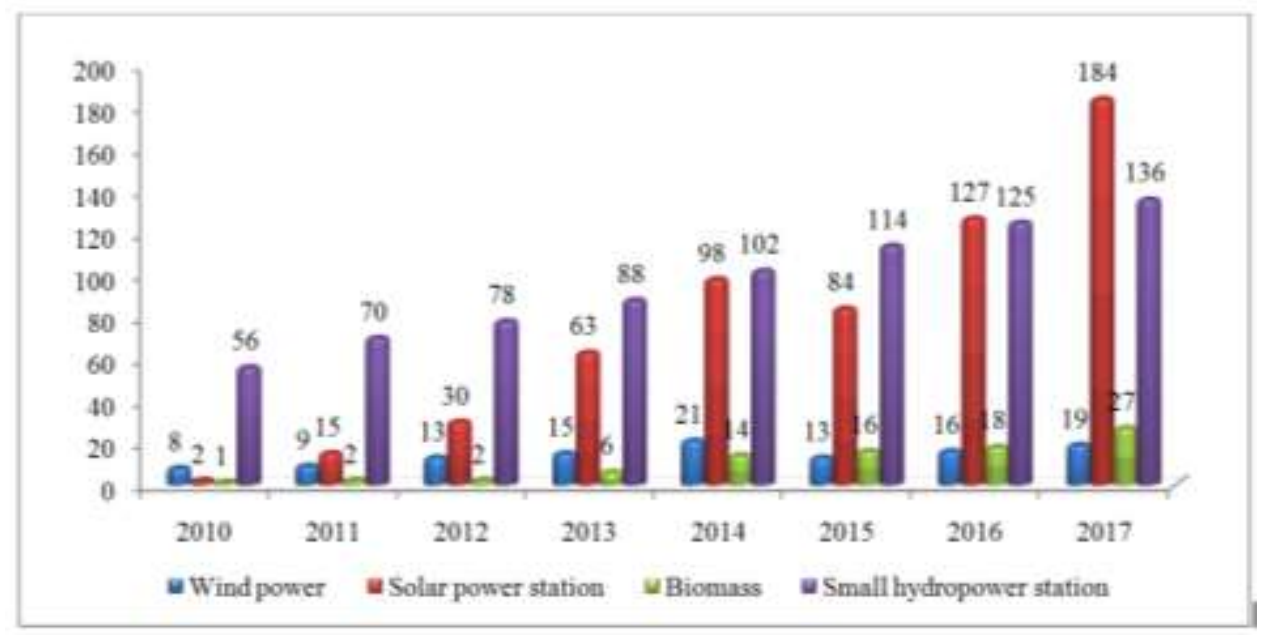

Fig. 1. Number of renewable energy generation by type in 2010-2017

Source: [8], own processing.

Acording to Fig. 1 in 2017 the most popular RES is Solar station (SPS) - 184 station, at the second place - Small hydropower station (SHS) - the number is 136 . The least popular are wind power and biomass [13]. In the first half of 2017 in Ukraine 79 new RES facilities were built, including 67 SPS. Their total capacity was $182.7 \mathrm{MW}$. The power of the SPS has increased by $23 \%$, or $132 \mathrm{MW}$, compared to the same data as of January 1, 2017 and amounted to $705 \mathrm{MW}$. According to the results of three quarters of 2017, the installed power of sources of alternative energy increased by $18 \%$ and amounted to $1320 \mathrm{MW}$. Also $201 \mathrm{MW}$ of new RES capacities was introduced, which is 3.7 times more than in the same period of the previous year. Among these capacities, $83 \%$ were solar power plants.

Recently, solar power plants are becoming very popular, in particular small private SPS, whose owners sell excess energy production at a green tariff. To date, in Ukraine there are 2,223 households have their own solar station connected to the common electricity grid. 
The segment of wind power plants has grown by $4.7 \%$, or by $20.7 \mathrm{MW}$, from the beginning of the year and amounted to $458.7 \mathrm{MW}$ of energy. The wind energy market is led by such companies as LLC "Ukrainian Wind Turbines of Ukraine", WindPower Ltd. and Windcraft Ukraine LLC.

An important renewable energy source in Ukraine is biomass and biogas. Over the last four years, the growth rate of production and use of biofuels has been around $42 \%$ per year. In 2017, the power of biomass and biogas power plants increased by $2 \mathrm{MW}$ and amounted to $33 \mathrm{MW}$ [9].

As of June 1, 2017, the total capacity of RES in Ukraine was 1461.7 MW. This includes wind and solar power plants, small hydro power plants, as well as power plants that operate on biofuels. So one of the most important tasks for today is to search for such energy sources that would reduce the use of traditional energy sources and reduce the dependence of these countries on imports. Currently, issues of energy independence are very relevant for Ukraine. The country's potential allows efficient use of RES, in particular solar and wind power, as well as biogas for the country's energy supply. The current Energy Strategy of Ukraine until 2035, as a whole, meets Ukraine's accrued obligations towards the EU on renewable energy sources and aims to increase the share of RES to $25 \%$ in 2035.

\subsection{Promising directions of development of cooperation between Ukraine and the EU in the field of RES}

Ukraine closely cooperates with the EU on the reform of corporate governance and the implementation of municipal projects. On May 17, 2017, Pavel Petrenko and Director of the European Bank for Reconstruction and Development, Frances Maliz, agreed on cooperation on energy, small and medium business support, and land reform. The EBRD provides Kyiv with significant advisory assistance on many issues. In addition, the EBRD has a dedicated USELF support program aimed at investing in REE. The program ranges from 500 million euros to 1 billion euros. The scheme of work of this program is quite simple and involves exclusively the co-financing of the project. That is, the EBRD agrees to finance $70 \%$ of the cost of the alternative energy facility, provided that $30 \%$ will be paid by the founders of the project or other sources of financing, while the own part of the costs must be invested in the project in the first place. Similarly, there are other banks and financial organizations in the EU that are ready to invest in alternative energy in Ukraine.

Significant potential for cooperation is represented by the International Agency for Renewable Sources IRENA. On October 5, 2017, the draft Law of Ukraine "On Ukraine's Accession to the Statute of the International Agency for Renewable Energy Sources (IRENA)" was submitted to the Verkhovna Rada for consideration, and on December 5 the law was passed. Membership in IRENA allows applications to the Abu Dhabi Development Fund to receive long-term loans at low interest rates. Admission to IRENA also provides additional guarantees to foreign investors regarding contributions to alternative energy projects in Ukraine.

In particular, the Finnish corporation "NEFCO" is interested in realization of "green" projects in Ukraine. Between this corporation and the State Energy Efficiency, negotiations are being held to create a joint venture that will produce materials and energy efficient equipment according to European technologies and standards.

On November 29, 2017, the Finnish Ministry of Foreign Affairs and NEFCO signed an agreement to create a fund for alternative energy projects in Ukraine [10], which interested Finnish businesses in investing in Ukrainian renewable energy projects.

Also, the Lviv region receives significant assistance in the implementation of environmental projects and clean energy projects. In 2017, the Eastern European Energy Efficiency and Environment Partnership and the John Nurminen Foundation provided 
grants to "Lvivvodocanal" to rebuild and renew the wastewater treatment and biogas production system.

On December 6, 2016, the Lviv Regional Administration signed a memorandum with the Turkish company Atlas GlobalEnergy LLC on the construction of a new wind power plant in the Skolevshchyna with a total capacity of $20 \mathrm{MW}$. Construction is scheduled to begin in 2018. Turkish investors are also planning to build a new wind farm within the Volovets and Svalyava districts of Lviv Oblast. The station will consist of 50 windmills and will have a total capacity of $120 \mathrm{MW}$.

Thus, it is relevant to identify the most promising directions for the development of cooperation between Ukraine and the EU in the field of alternative energy and implementation of RES. In addition to the EU and Ukraine, international and domestic actors are also domestic and foreign enterprises of all forms of ownership, consulting agencies, higher educational institutions and scientific research institutions. Today one of the most effective areas of cooperation is joint research in the field of alternative energy. To this direction, such forms of cooperation as realization of joint projects and initiatives, which leads to the creation of joint ventures, the allocation of international banks and funds of subsidies and loans $[11,12]$.

The second area of cooperation is the organization of cooperation at the expert level. It is this direction that is most widespread at the present stage, because it has a much lower level of risk. The forms of implementation of this direction are holding forums, meetings at the international level, consultations and recommendations of European experts in the field of legislative regulation of alternative energy, environmental taxation, implementation of environmental projects. Thus, for example, EBRD and IRENA are actively providing advisory services to Ukraine.

The third area of cooperation is to increase the level of environmental education of Ukraine's population in the field of alternative energy, which takes place in the form of organizing and conducting internships at higher education institutions in alternative energy companies, exchanging students, conducting international scientific conferences in this field.

\section{Discussion and Conclusion}

The performed scientific research allows us to formulate the following conclusions:

1. Due to climate change, the gradual depletion of traditional energy resources and the trend towards increased energy consumption and the desire of countries to reduce their dependence on imported fuels the development of alternative energy and the transition of farms to renewable energy sources is relevant.

2. One of the first attempts to regulate emissions was the Framework Convention on Climate Change. As we see, the Kyoto Protocol to the UNFCCC, which ended its operation in 2012, has proved ineffective. The Paris agreement has replaced it. International cooperation with the EU in the field of alternative energy has been going on for 25 years now. During this time, Ukraine has achieved some results in the field of alternative energy and use of RES.

3. According to the United Nations Framework Convention on Climate Change, the EU member states commit to reaching $20 \%$ of alternative energy in farms until 2020. According to the adopted commitments and the National Energy Strategy, Ukraine should achieve $11 \%$ renewable energy in the energy sector by 2020 and $25 \%$ by 2035 . The analysis led to the conclusion that the EU certainly achieved its goal in due time, but Ukraine plans look unrealistic because renewable energy in the country today are a very small proportion and require significant funding. 
4. An assessment of the current state of alternative energy sources in Ukraine has shown that the most promising are solar and wind energy, as well as the use of biofuels.

5. The prospect of international cooperation between Ukraine and the EU in the field of alternative energy is the development and implementation of "green energy" projects. The tool for this purpose in Ukraine is financing of such international organizations as EBRD, IBRD, NEFCO and IRENA. Further, there are own state sources of funding, as well as funds from private investors. The main areas of international cooperation are conducting joint scientific developments in the field of alternative energy, organizing cooperation at expert level, and raising the level of environmental education of Ukraine's population in the field of alternative energy. International cooperation should be based on the principles of partnership, innovation, strategic, coordination and coherence of action.

Thus, Ukraine and the countries of the European Union have been closely cooperating in the field of alternative energy for over 25 years. Recently, cooperation has deepened significantly, it includes not only investment projects, but also advising on reforms in the energy sector, support for small and medium-sized businesses, as well as land reform. Due to the investment of international organizations, private foreign investors and the implementation of joint projects, the share of RES in Ukraine's total energy production has increased significantly.

\section{References}

1. T. Avdeeva, Prospects for International Negotiations on Climate Change: Following the Copenhagen UN Conference. Biosphere, 1, 73-82, (2010).

2. Eurostat Statistics Explined. Energy from renewable sources [online]. Available at: http://ec.europa.eu/eurostat/statisticsexplained/index.php/Archive:Energy_from_renewable_sources (2018)

3. Initial report "Emissions Trading Research" [online]. Available at: http://climategroup.org.ua (2018)

4. A, Pochtovyuk, K. Pryakhina, Trade in Quotas as One of the Mechanisms of the Kyoto Protocol. Problems of Modern Economy, 3, 300-304, (2012)

5. I. Trofimova, Paris Agreement will stimulate modernization of Ukrainian economy [online]. Available at:

http://zhytlo.in.ua/ua/napryamok/chista_energya/rina_trofmova_parizka_ugoda_dast_p oshtovh_do_modernzac_ukransko_ekonomki.html (2018)

6. Ukraine's Energy Strategy for the period up to 2035: Security, Energy Efficiency, Competitiveness, 25.09.2017 [online]. Available at: http://mpe.kmu.gov.ua/minugol/control/uk/doccatalog/list?currDir=50358 (2017)

7. Power reform. Ukraine is capable of $74 \%$ of electricity produced from renewable sources [online]. Available at: http://reform.energy/news/ukraina-sposobna-74elektroenergii-proizvodit-iz-vozobnovlyaemykh-istochnikov-evrostat-3251 (2018)

8. The State Statistics Service of Ukraine [online]. Available at: www.ukrstat.gov.ua/ (2018)

9. G. Geletuha et al., Bioenergy in Ukraine: current state and development prospects. Part 2, Industrial Heat Engineering, 37(3), 65-73, (2015)

10. Ministry of Foreign Affairs of Finland and NEFCO Corporation have signed an agreement on the creation of a Trust Fund to finance Clean Energy Projects in Ukraine [online]. Available at: https://fromua.news/article/55259725/mzs-finlyandiita-korporatsiya-NEFCO-pidpisali-ugodu-pro-stvorennya-tsiljov/ (2018) 
11. A. Pochtovyuk, V. Semenikhina, Business relations between Ukraine and China: development options. SHS Web of Conferences, Innovative Economic Symposium 2017, 39, 01019, (2017)

12. J. Dušek, European Grouping of Territorial Cooperation as a Way of Cross-Border Regional Cooperation within the European Union. Conference Proceedings ,, 16th International Colloquium on Regional Sciences “, Brno, Czech Republic, 329-336, (2013)

13. Ukrainian Association of Renewable Energy [online]. Available at: http://uare.com.ua/ 